\title{
AKSESIBILITAS PERLINDUNGAN HUKUM BAGI TENAGA KERJA PENYANDANG DISABILITAS DI KABUPATEN KARAWANG*
}

\author{
Pamungkas Satya Putra** \\ Bagian Hukum Tata Negara \\ Fakultas Hukum, Universitas Singaperbangsa Karawang \\ Jalan H.S. Ronggowaluyo, Telukjambe Timur, Karawang, 41361
}

\begin{abstract}
Accessibility legal protection for every citizen to get a job is a fundamentalism as fundamental right in Indonesia. Karawang district has number persons with disabilities in 2016 to 6,237. The purpose research to analyze the legal protection of workers for persons with disabilities. The normative juridical research method carried out with a statutory approach the aim of the study providing more descriptive. The research result confirms lack of fulfillment the rights of persons with disabilities in employment with consequent yet to regulated the constitutional rights of citizens in Karawang Regulation can be applied to ensure the protection of the law.
\end{abstract}

Keywords: legal protection, labor, persons with disabilities.

\section{Intisari}

Aksesibilitas perlindungan hukum bagi setiap warga negara untuk mendapatkan pekerjaan merupakan landasan fundamental (fundamental grondslag) sebagai hak dasar (basic rights) di Republik Indonesia. Kabupaten Karawang memiliki jumlah penyandang disabilitas pada tahun 2016 berjumlah 6.237. Tujuan penelitian yaitu menganalisis perlindungan hukum tenaga kerja bagi penyandang disabilitas di Kabupaten Karawang. Metode penelitian yuridis normatif dilakukan dengan pendekatan analisis perundang-undangan dengan tujuan dan target penelitian memberikan argumentasi lebih terdeskripsi. Hasil penelitian menegaskan lemahnya pemenuhan hak bagi penyandang disabilitas di bidang ketenagakerjaan dengan belum diaturnya secara konsekuen untuk menjamin hak konstitusional warga negara dalam Peraturan Daerah Kabupaten Karawang dapat diaplikasikan untuk menjamin perlindungan hukum.

Kata Kunci: perlindungan hukum, tenaga kerja, penyandang disabilitas.

\section{Pokok Muatan}

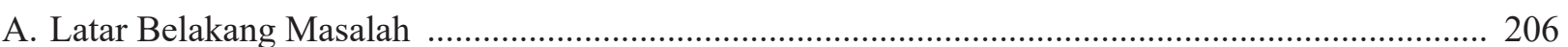

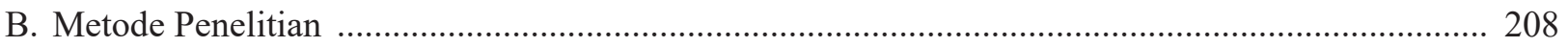

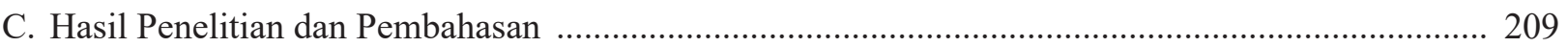

1. Aksesibilitas Perlindungan Hukum terhadap Tenaga Kerja bagi Penyandang Disabilitas di Kabupaten Karawang

2. Akibat Hukum Terhadap Perusahaan yang Tidak Mempekerjakan Paling Sedikit 1\% (satu persen) Penyandang Disabilitas dari Jumlah Pekerja di Kabupaten Karawang 216

D. Kesimpulan 218 


\section{A. Latar Belakang Masalah}

Konsideran menimbang huruf $a, b$, dan $c$ Undang-Undang Nomor 8 Tahun 2016 tentang Penyandang Disabilitas (selanjutnya ditulis UU Penyandang Disabilitas) menegaskan bahwa terdapat konsekuensi logis diperlukan pelaksanaan hak konstitusional penyandang disabilitas secara riil sebagaimana dituangkan dalam Pasal $28 \mathrm{H}$ ayat (2), Pasal 28I ayat (1), ayat (2), ayat (4), ayat (5), dan Pasal 28J Undang-Undang Dasar Negara Republik Indonesia Tahun 1945 dan Undang-Undang Nomor 19 Tahun 2011 tentang Pengesahan Convention on the Rights of Persons with Disabilities yang disahkan pada tanggal 10 November 2011. Pelaksanaan hak konstitusional penyandang disabilitas secara riil ini diatur lebih terperinci dalam UU Penyandang Disabilitas.

Selain itu, Negara Kesatuan Republik Indonesia memiliki kewajiban yakni menjamin kelangsungan hidup setiap warga negara, termasuk perlindungan hukum bagi para penyandang disabilitas yang mempunyai kedudukan hukum dan memiliki hak asasi manusia yang sama sebagai Warga Negara Indonesia. Seorang penyandang disabilitas adalah seorang manusia yang sama seperti manusia lainnya sebagai ciptaan Tuhan Yang Maha Esa dan memiliki hak dasar untuk hidup maju dan berkembang serta berkarya secara adil dan bermartabat. Faktanya dalam kehidupan seharihari, seseorang yang disematkan/disebut sebagai "penyandang disabilitas" tidak memperoleh akses, menikmati fasilitas, dan pelayanan publik seperti seorang yang tidak disabilitas.

Sebagian besar penyandang disabilitas di
Indonesia hidup dalam kondisi rentan, terbelakang, dan/atau miskin disebabkan masih adanya pembatasan, hambatan, kesulitan, dan pengurangan atau penghilangan hak penyandang disabilitas. Salah satu upaya untuk mewujudkan kesamaan hak dan kesempatan bagi penyandang disabilitas menuju kehidupan yang sejahtera, mandiri, dan tanpa diskriminasi diperlukan peraturan perundangundangan yang dapat menjamin pelaksanaannya. ${ }^{1}$

Konsep pemenuhan hak dan lemahnya aksesibilitas yang masih perlu perhatian dari masyarakat menjadi salah satu kendala bagi penyandang disabilitas khususnya di Indonesia dalam menjamin kedudukan hukum berdasarkan UU Penyandang Disabilitas. Salah satu dinamika yang terjadi yaitu penerapan pengaturan pada dunia kerja dan ketersediaan pemberian kesempatan kerja bagi penyandang disabilitas, khususnya di Kabupaten Karawang. Dinas Tenaga Kerja dan Transmigrasi Kabupaten Karawang seharusnya sudah memulai inventarisasi jumlah tenaga kerja penyandang disabilitas dan jumlah perusahaan yang mempekerjakan penyandang disabilitas, hal tersebut berdasarkan Undang-Undang Nomor 13 Tahun 2003 tentang Ketenagakerjaan jo. Surat Edaran Menteri Nomor 01.KP.01.15.2002 tentang Penempatan Tenaga Kerja Penyandang Cacat di Perusahaan yang ditujukan kepada Kepala Dinas Tenaga Kerja dan Transmigrasi di Provinsi dan Kabupaten/Kota.

Salah satu contoh kasus yang terjadi di PT Mondelez Indonesia, Klari, Kabupaten Karawang, yaitu pengusaha melakukan Pemutusan Hubungan Kerja (PHK) terhadap pekerja yang mengalami

\footnotetext{
Lihat Konsideran Menimbang dan Konsideran Mengingat Undang-Undang Nomor 8 Tahun 2016 tentang Penyandang Disabilitas. Lihat juga Penjelasan Atas Undang-Undang Nomor 8 Tahun 2016 tentang Penyandang Disabilitas Bagian I Umum (...) Penghormatan, Pelindungan, dan Pemenuhan Hak Penyandang Disabilitas merupakan kewajiban negara. Hal ini juga ditegaskan dalam Undang-Undang Nomor 39 Tahun 1999 tentang Hak Asasi Manusia, sehingga masyarakat mempunyai tanggung jawab untuk menghormati hak Penyandang Disabilitas. Penyandang Disabilitas selama ini mengalami banyak diskriminasi yang berakibat belum terpenuhinya pelaksanaan hak Penyandang Disabilitas. Selama ini, pengaturan mengenai Penyandang Disabilitas diatur dalam Undang-Undang Nomor 4 Tahun 1997 tentang Penyandang Cacat, tetapi pengaturan ini belum berperspektif hak asasi manusia. Materi muatan dalam Undang-Undang Nomor 4 Tahun 1997 tentang Penyandang Cacat lebih bersifat belas kasihan (charity based) dan pemenuhan hak penyandang disabilitas masih dinilai sebagai masalah sosial yang kebijakan pemenuhan haknya baru bersifat jaminan sosial, rehabilitasi sosial, bantuan sosial, dan peningkatan kesejahteraan sosial. Penyandang Disabilitas seharusnya mendapatkan kesempatan yang sama dalam upaya mengembangkan dirinya melalui kemandirian sebagai manusia yang bermartabat. Lihat juga Ismail Shaleh, "Implementasi Pemenuhan Hak Bagi Penyandang Disabilitas Ketenagakerjaan di Semarang", Kanun: Jurnal Ilmu Hukum, Vol. 20, No. 1, April 2018, hlm. 63-70.
} 
cacat tetap (disabilitas) akibat kecelakaan kerja. ${ }^{2}$ Maka Aksesibilitas tersebut seharusnya dapat diberlakukan bagi penyandang disabilitas akibat kecelakaan kerja. Kasus tersebut merupakan pelanggaran terhadap prinsip perlindungan penyandang disabilitas di dalam The Convention on the Rights of Persons with Disabilities (CRPD) yang telah diratifikasi, yaitu tidak dapat dilakukan perbuatan semena-mena di dalam kedudukan hukum sebagai pekerja".

Perlindungan hukum terhadap tenaga kerja penyandang disabilitas di Kabupaten Karawang tersebut mencerminkan belum terlaksananya Undang-Undang Nomor 13 Tahun 2003 tentang Ketenagakerjaan jo. Surat Edaran Menteri Nomor 01.KP.01.15.2002 tentang Penempatan Tenaga Kerja Penyandang Cacat di Perusahaan secara optimal, khususnya berkaitan dengan hak memperoleh kesempatan kerja di perusahaan bagi penyandang disabilitas. Tindakan hukum dalam hukum publik dapat dilakukan dengan memberikan sanksi pidana dan sanksi administratif, sedangkan tindakan hukum dalam hukum privat dengan meminta ganti rugi terhadap perusahaan yang tidak mempekerjakan paling sedikit 1\% (satu persen) dari jumlah pekerja berdasarkan Pasal 53 ayat (2) UU Penyandang Disabilitas.

Upaya hukum yang dapat dilakukan pekerja atas Pemutusan Hubungan Kerja karena kecelakaan kerja dan menimbulkan cacat tetap (disabilitas) adalah dengan melakukan upaya hukum hukum non-litigasi dan litigasi sebagai bentuk perlindungan hukum. ${ }^{3}$ Penyandang disabilitas memiliki kedudukan, hak, dan kewajiban yang sama dengan masyarakat nondisabilitas. Sebagai bagian dari warga negara Indonesia, sudah sepantasnya penyandang disabilitas mendapatkan perlakuan khusus, yang dimaksudkan sebagai upaya perlindungan dari kerentanan terhadap berbagai tindakan diskriminasi dan terutama perlindungan dari berbagai pelanggaran Hak Asasi Manusia. Keistimewaan dan perlakuan khusus tersebut dipandang sebagai upaya maksimalisasi penghormatan, pemajuan, perlindungan, dan pemenuhan Hak Asasi Manusia secara universal (sebagai bentuk diskriminasi positif). ${ }^{4}$

Aksesibilitas penyandang disabilitas yang masih tersisihkan dari masyarakat menjadi salah satu kendala bagi penyandang disabilitas khususnya di Indonesia. Adapun di Kabupaten Karawang, penerapan aksesibilitas penyandang disabilitas untuk mendapatkan akses sebagai pencari kerja maupun sebagai pekerja belum diatur lebih lanjut di dalam peraturan yang komprehensif guna menjamin kepastian hukum khususnya penerapan Pasal 53 ayat (2) UU Penyandang Disabilitas. Hal tersebut berdampak pada dunia kerja dan tersedianya kesempatan kerja bagi penyandang

\footnotetext{
Lihat Eta Yuni Lestari, et al., "Pemenuhan Hak Bagi Penyandang Disabilitas di Kabupaten Semarang Melalui Implementasi Convention on The Rights of Persons with Disabillities (CPRD) Dalam Bidang Pendidikan", Integralistik, No.1/Th. XXVIII/2017, Januari-Juni 2017, hlm. 5-9. Dengan disahkannya Undang-Undang Nomor 19 Tahun 2011 tentang Pengesahan Convention on the Rights of Persons with Disabilities (Konvensi Hak-hak Penyandang Disabilitas) tanggal 10 November 2011 menunjukkan komitmen dan kesungguhan Pemerintah Indonesia untuk menghormati, melindungi, dan memenuhi hak Penyandang Disabilitas yangpada akhirnya diharapkan dapat meningkatkan kesejahteraan Penyandang Disabilitas. Dengan demikian, Penyandang Disabilitas berhak untuk bebas dari penyiksaan atau perlakuan yang kejam, tidak manusiawi, merendahkan martabat manusia, bebas dari eksploitasi, kekerasan, dan perlakuan semena-mena, serta berhak untuk mendapatkan penghormatan atas integritas mental dan fisiknya berdasarkan kesamaan dengan orang lain, termasuk di dalamnya hak untuk mendapatkan pelindungan dan pelayanan sosial dalam rangka kemandirian, serta dalam keadaan darurat. Oleh karena itu, Pemerintah berkewajiban untuk merealisasikan hak yang termuat dalam konvensi, melalui penyesuaian peraturan perundang-undangan, termasuk menjamin pemenuhan hak Penyandang Disabilitas dalam segala aspek kehidupan, seperti pendidikan, kesehatan, pekerjaan, politik dan pemerintahan, kebudayaan dan kepariwisataan, serta pemanfaatan teknologi, informasi, dan komunikasi.

Jangkauan pengaturan dalam Undang-Undang ini meliputi pemenuhan kesamaan kesempatan terhadap Penyandang Disabilitas dalam segala aspek penyelenggaraan negara dan masyarakat, penghormatan, perlindungan, dan pemenuhan hak Penyandang Disabilitas, termasuk penyediaan aksesibilitas dan akomodasi yang layak. Pengaturan pelaksanaan dan pemenuhan hak Penyandang Disabilitas bertujuan untuk mewujudkan taraf kehidupan Penyandang Disabilitas yang lebih berkualitas, adil, sejahtera lahir dan batin, serta bermartabat. Selain itu, pelaksanaan dan pemenuhan hak juga ditujukan untuk melindungi Penyandang Disabilitas dari penelantaran dan eksploitasi, pelecehan dan segala tindakan diskriminatif, serta pelanggaran hak asasi manusia. Lihat juga Mary Ann Jackson, "Models of Disability and Human Rights: Informing the Improvement of Built Environment Accessibility for People with Disability at Neighborhood Scale?”, Laws, Vol. 7, $10,2018$. Majda El Muhtaj, 2008, Dimensi-dimensi HAM Mengurai Hak Ekonomi, Sosial dan Budaya, PT RajaGrafindo Persada, Jakarta, hlm. 275. Lihat juga Jody Heymann, et al., 2013, Disability and Equity at Work, Oxford University Press, UK, hlm. 5-12.
} 
disabilitas di Indonesia. Pasal 27 ayat (2) UndangUndang Dasar Negara Republik Indonesia Tahun 1945 menegaskan bahwa:

"Tiap-tiap warga negara berhak atas pekerjaan dan penghidupan yang layak bagi kemanusiaan". ${ }^{5}$

Hak bagi warga negara sebagai pekerja juga diatur dalam Pasal 28D Undang-Undang Dasar Negara Republik Indonesia Tahun 1945 yang menegaskan bahwa:

"Setiap orang berhak untuk bekerja serta mendapatkan imbalan dan perlakuan yang adil dan layak dalam hubungan kerja". ${ }^{6}$

Penjelasan Pasal 5 Undang-Undang Nomor 13 Tahun 2003 tentang Ketenagakerjaan menegaskan bahwa:

"Setiap tenaga kerja mempunyai hak dan kesempatan yang sama untuk memperoleh pekerjaan dan penghidupan yang layak tanpa membedakan jenis kelamin, suku, ras, agama, dan aliran politik sesuai dengan minat dan kemampuan tenaga kerja yang bersangkutan, termasuk perlakuan yang sama terhadap para penyandang cacat."

Berdasarkan hal tersebut di atas, penulis tertarik untuk meninjau dan mengkaji lebih dalam tentang aksesibilitas perlindungan hukum bagi tenaga kerja penyandang disabilitas, maka rumusan masalah yang diangkat dalam tulisan ini adalah: Pertama, Bagaimanakah aksesibilitas perlindungan hukum terhadap tenaga kerja bagi penyandang disabilitas di Kabupaten Karawang?; Kedua, Bagaimanakah akibat hukum terhadap perusahaan yang tidak mempekerjakan paling sedikit 1\% (satu persen) penyandang disabilitas dari jumlah pekerja di Kabupaten Karawang?

\section{B. Metode Penelitian}

Penelitian ini dilakukan secara sistematis dengan menggunakan jenis penelitian yuridis normatif. Penelitian yuridis normatif merupakan penelitian hukum kepustakaan yang dilakukan dengan cara meneliti bahan-bahan kepustakaan atau data sekunder. ${ }^{8}$ Penelitian tersebut difokuskan untuk mengkaji penerapan kaidah-kaidah atau norma-norma dalam hukum positif khususnya aksesibilitas perlindungan hukum bagi tenaga kerja di Kabupaten Karawang. ${ }^{9}$ Sifat penelitian yang digunakan adalah penelitian deskriptif yaitu suatu penelitian yang bertujuan untuk memberikan gambaran atau penjelasan ${ }^{10}$ secara konkret tentang keadaan objek atau masalah yang diteliti tanpa mengambil kesimpulan secara umum. ${ }^{11}$

Data dalam penulisan ini adalah data sekunder, yaitu bahan pustaka yang mencakup dokumen-dokumen resmi, buku-buku perpustakaan, peraturan perundang-undangan, karya ilmiah, artikel-artikel, serta dokumen yang berkaitan dengan materi penelitian. ${ }^{12}$ Teknik pengumpulan data penelitian hukum ini adalah melalui studi kepustakaan. ${ }^{13}$ Penelitian ini juga menggunakan teknik wawancara dengan beberapa narasumber yang dianggap relevan dengan penelitian ini. Hasil wawancara merupakan data tambahan dalam penelitian yuridis normatif ini. ${ }^{14}$ Data yang diperoleh dalam penelitian ini dianalisis dengan menggunakan analisis kualitatif. ${ }^{15}$ Lokasi penelitian dan narasumber adalah Kantor Dinas Tenaga Kerja dan Transmigrasi (Disnakertras), Balai Pelayanan

\footnotetext{
Pasal 27 ayat (2) Undang-Undang Dasar Negara Republik Indonesia Tahun 1945.

Pasal 28D Undang-Undang Dasar Negara Republik Indonesia Tahun 1945.

Pasal 5 Undang-Undang Nomor 13 Tahun 2003 tentang Ketenagakerjaan (Lembaran Negara Republik Indonesia Tahun 2003 Nomor 39 , Tambahan Lembaran Negara Republik Indonesia Nomor 4279).

Soerjono Soekanto, et al., 2011, Penelitian Hukum Normatif, Suatu Tinjauan Singkat, PT RajaGrafindo Persada, Jakarta, hlm. 13.

Philipus M. Hadjon, et. al., 2016, Argumentasi Hukum, Gadjah Mada University Press, Yogyakarta, hlm. 9.

Soerjono Soekanto, 2010, Pengantar Penelitian Hukum, UI Press, Jakarta, hlm. 10.

Soerjono Soekanto, et al., Op.cit., hlm. 12.

Ibid., hlm. 13.

Sigit Riyanto, et. al., 2013, Keterampilan Hukum: Panduan untuk Mahasiswa, Akademisi dan Praktisi, Gadjah Mada University Press, Yogyakarta, hlm. 179

Fajlurrahman Jurdi, 2017, Logika Hukum, Penerbit Kencana, Jakarta, hlm. 187.

Philipus M. Hadjon, Op.cit., hlm. 30.
} 
Pengawasan Ketenagakerjaan Wilayah II, dan Kantor Dinas Sosial Kabupaten Karawang. ${ }^{16}$

\section{Hasil Penelitian dan Pembahasan}

1. Aksesibilitas Perlindungan Hukum terhadap Tenaga Kerja bagi Penyandang Disabilitas di Kabupaten Karawang

Istilah penyandang disabilitas disebutkan dalam Pasal 1 angka 1 UU Penyandang Disabilitas yang menentukan bahwa:

"Penyandang Disabilitas adalah setiap orang yang mengalami keterbatasan fisik, intelektual, mental, dan/atau sensorik dalam jangka waktu lama yang dalam berinteraksi dengan lingkungan dapat mengalami hambatan dan kesulitan untuk berpartisipasi secara penuh dan efektif dengan warga negara lainnya berdasarkan kesamaan hak". ${ }^{17}$

UU Penyandang Disabilitas mengenalkan istilah aksesibilitas. Setidak-tidaknya terdapat 21 (dua puluh satu) kata aksesibilitas dalam undangundang tersebut. Bab I Ketentuan Umum Pasal 1 angka 8 menegaskan aksesibilitas sebagai akses kemudahan yang disediakan untuk Penyandang Disabilitas guna mewujudkan Kesamaan Kesempatan. ${ }^{18}$ Pasal 2 mengatur Pelaksanaan dan Pemenuhan hak Penyandang Disabilitas berasaskan "aksesibilitas". ${ }^{19}$ Aksesibilitas merupakan bagian dari kehidupan manusia dalam kehidupannya, sehingga aksesibilitas merupakan hal yang utama karena untuk mengakomodir aktivitas manusia, aksesibilitas sangat penting untuk penyandang disabilitas. Prinsip persamaan tersebut merupakan kesempatan, diartikan sebagai keadaan yang memberikan upaya pemerataan atau menyediakan akses kepada difabel untuk menyalurkan potensi dalam segala aspek penyelenggaraan negara dan masyarakat. Tujuan dari aksesibilitas adalah untuk memberikan kemudahan bagi penyandang disabilitas dalam melakukan aktivitas seharihari serta memiliki kesempatan dan peluang yang sama dalam memperoleh pelayanan publik untuk

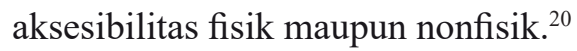

Pasal 148 UU Penyandang Disabilitas, menentukan bahwa istilah Penyandang Cacat yang dipakai dalam peraturan perundang-undangan yang sudah ada sebelum undang-undang tersebut berlaku, harus dibaca dan dimaknai sebagai Penyandang Disabilitas, sepanjang tidak bertentangan dengan UU Penyandang Disabilitas. ${ }^{21}$ Menurut Pasal 4 ayat (1), Ragam Penyandang Disabilitas meliputi: a. Penyandang Disabilitas fisik; b. Penyandang Disabilitas intelektual; c. Penyandang Disabilitas mental; dan/atau d. Penyandang Disabilitas sensorik". ${ }^{22}$

Menurut penjelasan Pasal 4 ayat (1) huruf a sampai dengan huruf d UU Penyandang Disabilitas menyebutkan bahwa: ${ }^{23}$

1. $\quad$ Yang dimaksud dengan "Penyandang Disabilitas fisik" adalah terganggunya fungsi gerak, antara lain amputasi, lumpuh layuh atau kaku, paraplegi,

Sigit Riyanto, et. al., Op.cit., hlm. 180.

17 Pasal 1 angka 1 Undang-Undang Nomor 8 Tahun 2016 tentang Penyandang Disabilitas (Lembaran Negara Republik Indonesia Tahun 2016 Nomor 69, Tambahan Lembaran Negara Republik Indonesia Nomor 5817).

18 Pasal 1 angka 8 Undang-Undang Nomor 8 Tahun 2016 tentang Penyandang Disabilitas (Lembaran Negara Republik Indonesia Tahun 2016 Nomor 69, Tambahan Lembaran Negara Republik Indonesia Nomor 5817).

19 Pasal 2 Undang-Undang Nomor 8 Tahun 2016 tentang Penyandang Disabilitas (Lembaran Negara Republik Indonesia Tahun 2016 Nomor 69 , Tambahan Lembaran Negara Republik Indonesia Nomor 5817).

20 Jangkauan pengaturan dalam undang-undang tersebut meliputi Pemenuhan Kesamaan Kesempatan terhadap Penyandang Disabilitas dalam segala aspek penyelenggaraan Negara dan masyarakat Penghormatan, Perlindungan, dan Pemenuhan hak Penyandang Disabilitas, termasuk penyediaan Aksesibilitas dan Akomodasi yang Layak. Pengaturan pelaksanaan dan Pemenuhan hak Penyandang Disabilitas bertujuan untuk mewujudkan taraf kehidupan Penyandang Disabilitas yang lebih berkualitas, adil, sejahtera lahir dan batin, serta bermartabat. Selain itu, pelaksanaan dan Pemenuhan hak juga ditujukan untuk melindungi Penyandang Disabilitas dari penelantaran dan eksploitasi pelecehan dan segala tindakan diskriminatif, serta pelanggaran hak asasi manusia.

21 Pasal 148 Undang-Undang Nomor 8 Tahun 2016 tentang Penyandang Disabilitas (Lembaran Negara Republik Indonesia Tahun 2016 Nomor 69, Tambahan Lembaran Negara Republik Indonesia Nomor 5817).

22 Pasal 4 ayat (1) Undang-Undang Nomor 8 Tahun 2016 tentang Penyandang Disabilitas (Lembaran Negara Republik Indonesia Tahun 2016 Nomor 69, Tambahan Lembaran Negara Republik Indonesia Nomor 5817).

23 Ibid. 
celebral palsy (CP), akibat stroke, akibat kusta, dan orang kecil.

2. $\quad$ Yang dimaksud dengan "Penyandang Disabilitas intelektual" adalah terganggunya fungsi pikir karena tingkat kecerdasan di bawah rata-rata, antara lain lambat belajar, disabilitas grahita dan down syndrom.

3. $\quad$ Yang dimaksud dengan "Penyandang Disabilitas mental" adalah terganggunya fungsi pikir, emosi, dan perilaku, antara lain:

a. Psikososial di antaranya skizofrenia, bipolar, depresi, anxietas, dan gangguan kepribadian; dan

b. Disabilitas perkembangan yang berpengaruh pada kemampuan interaksi sosial di antaranya autis dan hiperaktif.

4. Yang dimaksud dengan "Penyandang Disabilitas sensorik" adalah terganggunya salah satu fungsi dari panca indera, antara lain disabilitas netra, disabilitas rungu, dan/atau disabilitas wicara.

Seseorang dapat menjadi penyandang disabilitas (cacat) karena mengalami kecelakaan kerja. Sebagaimana dikemukakan Zaeni Asyhadie, kecelakaan kerja adalah risiko yang dihadapi oleh tenaga kerja yang melakukan pekerjaan, karena pada umumnya kecelakaan bisa jadi akan mengakibatkan: ${ }^{24}$

1. Kematian, yaitu kecelakaan-kecelakaan yang mengakibatkan penderitanya bisa meninggal dunia.

2. Cacat atau tidak berfungsinya sebagian dari anggota tubuh tenaga kerja yang menderita kecelakaan. Cacat ini terdiri dari:

a. Cacat Tetap, yaitu kecelakaankecelakaan yang mengakibatkan penderitanya mengalami pembatasan atau gangguan fisik atau mental yang bersifat tetap.

b. Cacat Sementara, yaitu kecelakaan-kecelakaan yang mengakibatkan penderitanya menjadi tidak mampu bekerja untuk sementara waktu.

Merujuk pada Undang-Undang Nomor 40 Tahun 2004 tentang Sistem Jaminan Sosial Nasional, terdapat 2 (dua) istilah cacat, yaitu cacat dan cacat total tetap. ${ }^{25}$ Cacat merupakan keadaan berkurangnya atau hilangnya fungsi tubuh atau hilangnya anggota badan yang secara langsung atau tidak langsung mengakibatkan berkurang atau hilangnya kemampuan pekerja untuk menjalankan pekerjaannya. ${ }^{26}$ Sementara, yang dimaksud cacat total tetap adalah cacat yang mengakibatkan ketidakmampuan seseorang untuk melakukan pekerjaan. ${ }^{27}$ Ketidakmampuan bekerja secara tetap atau total, dapat mengakibatkan timbulnya risiko ekonomis bagi penderitanya.

Sejatinya konsepsi Hak Asasi Manusia sebagai salah satu pilar utama pengejawantahan negara modern dalam bagian dari instrumen negara hukum (rechtsstaats atau rule of law) ${ }^{28}$ Hal tersebut dimaksudkan untuk mengatur tentang Hak Asasi Manusia yang harus dilindungi dan dilaksanakan oleh pemerintah Republik Indonesia sebagai negara hukum. Penguatan terhadap mekanisme perlindungan hukum bagi tenaga kerja penyandang disabilitas didasarkan pada Prinsip Kesetaraan dan Prinsip Non-Diskriminasi.

Pasal 1 angka 3 Undang-Undang Nomor 39 Tahun 1999 tentang Hak Asasi Manusia menjelaskan bahwa:

Zaeni Asyhadie, Op.cit., hlm. 122.

Undang-Undang Nomor 40 Tahun 2004 tentang Sistem Jaminan Sosial Nasional (Lembaran Negara Republik Indonesia Tahun 2004 Nomor 150, Tambahan Lembaran Negara Republik Indonesia Nomor 5256).

26 Pasal 1 angka 15 Undang-Undang Nomor 40 Tahun 2004 tentang Sistem Jaminan Sosial Nasional (Lembaran Negara Republik Indonesia Tahun 2004 Nomor 150, Tambahan Lembaran Negara Republik Indonesia Nomor 5256).

27 Pasal 1 angka 16 Undang-Undang Nomor 40 Tahun 2004 tentang Sistem Jaminan Sosial Nasional (Lembaran Negara Republik Indonesia Tahun 2004 Nomor 150, Tambahan Lembaran Negara Republik Indonesia Nomor 5256).

28 Lihat juga JJ. von Schmid, 1962, Ahli-ahli Pemikir Besar tentang Negara dan Hukum (dari Plato sampai Kant), (Diterjemahkan oleh R. Wiranto, et al.), PT Pembangunan, Jakarta, hlm. 8. 
"Diskriminasi adalah setiap pembatasan, pelecehan, atau pengucilan yang langsung ataupun tak langsung didasarkan pada pembedaan manusia atas dasar agama, suku, ras, etnik, kelompok, golongan, status sosial, status ekonomi, jenis kelamin, bahasa, keyakinan politik yang berakibat pengurangan, penyimpangan atau penghapusan pengakuan, pelaksanaan atau penggunaan hak asasi manusia, dan kebebasan dasar dalam kehidupan, baik individual maupun kolektif, dalam bidang politik, ekonomi, hukum, sosial, budaya, dan aspek kehidupan lainnya". ${ }^{29}$

Hal lebih lanjut diatur dalam Pasal 38 Undang-Undang Nomor 39 Tahun 1999 tentang Hak Asasi Manusia juga menyatakan bahwa:

“(1) Setiap warga negara, sesuai dengan bakat, kecakapan, dan kemampuan, berhak atas pekerjaan yang layak; (2) Setiap orang berhak dengan bebas memilih pekerjaan yang disukainya dan berhak pula atas syarat-syarat ketenagakerjaan yang adil; (3) Setiap orang, baik pria maupun wanita yang melakukan pekerjaan yang sama, sebanding, setara atau serupa, berhak atas upah serta syaratsyarat perjanjian kerja yang sama; (4) Setiap orang, baik pria maupun wanita, dalam melakukan pekerjaan yang sepadan dengan martabat kemanusiaannya berhak atas upah yang adil sesuai dengan prestasinya dan dapat menjamin kelangsungan kehidupan keluarganya".30

Hak atas pekerjaan dan hak dalam bekerja merupakan Hak Asasi Manusia. Perlindungan dan pemenuhan hak tersebut memberikan arti penting bagi pencapaian standar kehidupan yang layak. Pemerintah memiliki kewajiban untuk merealisasikan hak itu dengan sebaik-baiknya. ${ }^{31}$
Tujuan perlindungan kerja adalah untuk menjamin berlangsungnya sistem hubungan kerja secara harmonis tanpa disertai adanya tekanan dari pihak yang kuat kepada pihak yang lemah. ${ }^{32}$ Menurut Zaeni Asyhadie, perlindungan kerja dapat dilakukan baik dengan jalan memberikan tuntunan, santunan, maupun dengan jalan meningkatkan pengakuan hak-hak asasi manusia, perlindungan fisik, dan sosial ekonomi melalui norma yang berlaku dalam perusahaan. ${ }^{33}$

Berdasarkan hal tersebut Pemerintah Pusat dan Pemerintah Daerah Kabupaten Karawang berkewajiban menjamin aksesibilitas hak atas pekerjaan dan hak dalam bekerja setiap warga negara yang merupakan bagian dari Hak Asasi Manusia. ${ }^{34}$ Hal tersebut berlaku juga untuk penyandang disabilitas. Pasal 52 UU Penyandang Disabilitas menyebutkan bahwa:

"Pemerintah dan Pemerintah Daerah wajib menjamin akses yang setara bagi Penyandang Disabilitas terhadap manfaat dan program dalam sistem jaminan sosial nasional di bidang ketenagakerjaan". 35

Pelarangan terhadap diskriminasi adalah salah satu bagian penting prinsip kesetaraan. Jika semua orang setara, maka seharusnya tidak ada perlakuan yang diskriminatif (selain tindakan afirmatif yang dilakukan untuk mencapai kesetaraan). Pasal 1 angka 3 Undang-Undang Nomor 39 Tahun 1999 tentang Hak Asasi Manusia lebih jelas mendefinisikan diskriminasi sebagai:

"Diskriminasi adalah setiap pembatasan, pelecehan, atau pengecualian yang langsung ataupun tidak langsung didasarkan pada pembedaan manusia atas dasar agama, suku,

\footnotetext{
Pasal 1 angka 3 Undang-Undang Nomor 39 Tahun 1999 tentang Hak Asasi Manusia (Lembaran Negara Republik Indonesia Tahun 1999 Nomor 165, Tambahan Lembaran Negara Republik Indonesia Nomor 3886).

30 Pasal 38 Undang-Undang Nomor 39 Tahun 1999 tentang Hak Asasi Manusia (Lembaran Negara Republik Indonesia Tahun 1999 Nomor 165 , Tambahan Lembaran Negara Republik Indonesia Nomor 3886).

31 Majda El Muhtaj, Op.cit, hlm. 181. Lihat juga Andrie Irawan, "Peranan Pemerintah Daerah Istimewa Yogyakarta Dalam Perlindungan Hukum Terhadap Perempuan Penyandang Disabilitas Korban Kekerasan”, Jurnal Ilmiah Hukum De'Jure: Kajian Ilmiah Hukum, Vol. 2, No. 2, 2017, hlm. 204-210.

32 Abdul Khakim, 2014, Dasar-Dasar Hukum Ketenagakerjaan Indonesia, Cetakan ke-4, PT Citra Aditya Bakti, Bandung, hlm. 99. Zaeni Asyhadie, 2015, Hukum Kerja: Hukum Ketenagakerjaan Bidang Hubungan Kerja, PT RajaGrafindo Persada, Jakarta, hlm. 84. R. Abdoel Djamali, 2014, Pengantar Hukum Indonesia, PT RajaGrafindo Persada, Jakarta, hlm. 138.

Pasal 52 Undang-Undang Nomor 8 Tahun 2016 tentang Penyandang Disabilitas (Lembaran Negara Republik Indonesia Tahun 2016 Nomor 69, Tambahan Lembaran Negara Republik Indonesia Nomor 5817).
} 
ras, etnik, kelompok, golongan, status sosial, status ekonomi, jenis kelamin, bahasa, keyakinan politik, yang berakibat, pengurangan, penyimpangan atau penghapusan, pengakuan, pelaksanaan atau penggunaan hak asasi manusia dan kebebasan dasar dalam kehidupan baik individual maupun kolektif dalam bidang politik, ekonomi, hukum, sosial, budaya, dan aspek kehidupan lainnya" ${ }^{36}$

Selanjutnya dalam Pasal 53 ayat (1) dan ayat (2) UU tentang Penyandang Disabilitas menyebutkan bahwa: ${ }^{37}$

(1) Pemerintah, Pemerintah Daerah, Badan Usaha Milik Negara, dan Badan Usaha Milik Daerah wajib mempekerjakan paling sedikit $2 \%$ (dua persen) Penyandang Disabilitas dari jumlah pegawai atau pekerja.

(2) Perusahaan swasta wajib mempekerjakan paling sedikit 1\% (satu persen) Penyandang Disabilitas dari jumlah pegawai atau pekerja.

Menurut Pasal 1 angka 2 Undang-Undang Nomor 13 Tahun 2003 tentang Ketenagakerjaan, yang disebut sebagai tenaga kerja adalah:

"Setiap orang yang mampu melakukan pekerjaan guna menghasilkan barang dan/ atau jasa baik untuk memenuhi kebutuhan sendiri maupun untuk masyarakat". ${ }^{38}$

Definisi tenaga kerja menurut UndangUndang Nomor 13 Tahun 2003 tentang Ketenagakerjaan di atas sejalan dengan definisi tenaga kerja menurut konsep ketenagakerjaan oleh Payaman J. Simanjuntak yang mendefinisikan tenaga kerja atau manpower mencakup penduduk yang sudah atau sedang bekerja, yang sedang mencari kerja, dan yang melakukan pekerjaan lain, seperti sekolah dan mengurus rumah tangga. ${ }^{39}$ Jadi semata-mata dilihat dari batas umur, untuk kepentingan sensus di Indonesia menggunakan batas umur minimum 15 tahun dan batas umur maksimum 55 tahun. ${ }^{40} \mathrm{Hal}$ tersebut di atas dapat menjadi acuan tinjauan yuridis terhadap perlindungan hukum tenaga kerja bagi penyandang disabilitas di Kabupaten Karawang yang belum memiliki korelasi yang jelas dalam melaksanakan amanat Undang-Undang Dasar dengan lemahnya segi pengaturan penyandang disabilitas.

Berkaitan dengan aksesibilitas terhadap perlindungan hukum bagi buruh atau tenaga kerja khusus penyandang disabilitas, menurut Iman Soepomo perlindungan hukum tenaga kerja dibagi menjadi 3 (tiga) macam yaitu: ${ }^{41}$

(1) Perlindungan ekonomis, yaitu jenis perlindungan yang berkaitan dengan usaha-usaha untuk memberikan kepada pekerja suatu penghasilan yang cukup memenuhi kebutuhan seharihari baginya beserta keluarganya, termasuk dalam hal pekerja tersebut tidak mampu bekerja karena sesuatu di luar kehendakya. Termasuk dalam perlindungan ekonomis, antara lain perlindungan upah, Jamsostek, dan THR;

(2) Perlindungan sosial, yaitu suatu perlindungan berkaitan dengan usaha kemasyarakatan, yang tujuannya memungkinkan pekerja untuk mengenyam dan memperkembangkan perikehidupan sebagai manusia pada umumnya dan sebagai anggota masyarakat dan anggota keluarga. Perlindungan sosial tersebut meliputi perlindungan terhadap buruh anak, buruh perempuan, pengusaha wajib memberikan waktu istirahat dan cuti;

\footnotetext{
6 Pasal 1 angka 3 Undang-Undang Nomor 39 Tahun 1999 tentang Hak Asasi Manusia (Lembaran Negara Republik Indonesia Tahun 1999 Nomor 165, Tambahan Lembaran Negara Republik Indonesia Nomor 3886).

37 Pasal 53 ayat (1) dan ayat (2) Undang-Undang Nomor 8 Tahun 2016 tentang Penyandang Disabilitas (Lembaran Negara Republik Indonesia Tahun 2016 Nomor 69, Tambahan Lembaran Negara Republik Indonesia Nomor 5817).

38 Pasal 1 angka 2 Undang-Undang Nomor 13 Tahun 2003 tentang Ketenagakerjaan (Lembaran Negara Republik Indonesia Tahun 2003 Nomor 39, Tambahan Lembaran Negara Republik Indonesia Nomor 4279).

39 Payaman J. Simanjuntak, 1985, Pengantar Ekonomi Sumber Daya Manusia, Fakultas Ekonomi UI, Jakarta, hlm.2.

$40 \quad$ Ibid., hlm. 27.

41 Iman Soepomo, 1985, Pengantar Hukum Perburuhan, Djambatan, Jakarta, hlm. 97.
} 
(3) Perlindungan teknis, yaitu perlindungan yang berkaitan dengan usaha-usaha untuk menjaga pekerja dari bahaya kecelakaan yang dapat ditimbulkan oleh pesawat-pesawat atau oleh alat kerja lainnya atau bahan-bahan yang diolah atau dikerjakan oleh perusahaan. Perlindungan teknis ini berkaitan dengan K3 (Keselamatan dan Kesehatan Kerja), yaitu perlindungan ketenagakerjaan yang bertujuan agar buruh dapat terhindar dari segala risiko bahaya yang mungkin timbul di tempat kerja, baik disebabkan oleh alat-alat atau bahan-bahan yang dikerjakan dari suatu hubungan kerja.

Tahun 2016 jumlah penduduk Kabupaten Karawang mencapai 2.295.778 jiwa. Angka ini didapatkan dari hasil proyeksi dan angka tersebut masih sementara. Penduduk laki-laki pada tahun 2016 berjumlah 1.177 .310 jiwa dan penduduk perempuan berjumlah 1.118.468 jiwa, sedangkan jumlah penyandang cacat (atau dalam penggunaan kata penghalusan sebagai penyataraan disebut dengan penyandang disabilitas) berjumlah 6.237 jiwa. Hal tersebut dapat dilihat dalam Tabel
1.1 Jumlah Penduduk dan Penyandang Cacat (Penyandang Disabilitas) di Kabupaten Karawang Tahun 2016. ${ }^{42}$

\section{Tabel 1.1}

\section{Jumlah Penduduk dan Penyandang Cacat (Penyandang Disabilitas) di Kabupaten Karawang Tahun 2016}

\begin{tabular}{|c|c|c|}
\hline No. & Uraian & Jumlah \\
\hline 1. & Jumlah penduduk & 2.295 .778 \\
\hline 2. & Komposisi menurut kelamin: & \\
\hline & a. Laki-laki & 1.177 .310 \\
\hline & b. Perempuan & 1.118 .468 \\
\hline 3. & Penyandang Cacat & 6.237 \\
\hline
\end{tabular}

Sumber: BPS Kabupaten Karawang, 2016.

Berdasarkan sumber data tersebut juga diketahui bahwa jumlah angkatan kerja di Kabupaten Karawang adalah 987.688 jiwa. Jumlah penduduk yang bekerja adalah 873.995 jiwa, sedangkan jumlah penduduk yang menjadi pengangguran terbuka adalah 113.693 jiwa. Hal tersebut dapat dilihat dalam Tabel 1.2 Jumlah Penduduk Berumur 15 Tahun Keatas Menurut Jenis Kegiatan Selama Seminggu yang Lalu dan Jenis Kelamin di Kabupaten Karawang Tahun 2015. ${ }^{43}$

Tabel 1.2

Jumlah Penduduk Berumur 15 Tahun Keatas Menurut Jenis Kegiatan Selama Seminggu yang Lalu dan Jenis Kelamindi Kabupaten Karawang, Tahun 2015

\begin{tabular}{llrrr}
\hline \multirow{2}{*}{ No. Kegiatan Utama } & \multicolumn{2}{c}{ Jenis Kelamin } & Jumlah \\
\cline { 2 - 3 } & & Laki-laki & Perempuan & \\
\hline 1. & Angkatan Kerja: & 722.095 & 265.593 & 987.688 \\
\hline a. Bekerja & 644.308 & 229.687 & 873.995 \\
\hline b. Pengangguran Terbuka & 77.787 & 35.906 & 113.693 \\
\hline 2. Bukan Angkatan Kerja: & 138.099 & 550.992 & 689.091 \\
\hline a. Sekolah & 77.170 & 65.241 & 142.411 \\
\hline b. Mengurus Rumah Tangga & 2.893 & 453.570 & 456.463 \\
\hline c. Lainnya & 58.036 & 32.181 & 90.217 \\
\hline Jumlah & 860.194 & 816.585 & 1.676 .779 \\
\hline
\end{tabular}

Sumber: BPS Kabupaten Karawang, 2016.44

42 Badan Pusat Statistik Kabupaten Karawang, "Kabupaten Karawang dalam Angka 2017”, https://karawangkab.bps.go.id/publication/2017/0 8/17/258839c82b4aaf001be0f08f/kabupaten-karawang-dalam-angka-2017.html, diakses 20 November 2017. Sampai dengan saat ini belum terdapat pemutakhiran data dan inventarisasi jumlah penyandang disabilitas yang dilakukan oleh Badan Pusat Statistik Kabupaten Karawang. 
Sumber data BPS Kabupaten Karawang 2016 tersebut, belum dapat mendeskripsikan jumlah tenaga kerja penyandang disabilitas yang bekerja di Kabupaten Karawang beserta lapangan usahanya. Adapun data dari Komisi Pemilihan Umum Kabupaten Karawang, jumlah penyandang disabilitas yang sudah mempunyai hak pilih di Kabupaten Karawang berdasarkan Data Pemilih Tetap Pilkada Serentak Tahun 2015 adalah 690 orang. ${ }^{45}$ Data tersebut dapat menjadi acuan jumlah tenaga kerja penyandang disabilitas di Kabupaten Karawang. ${ }^{46}$

Berdasarkan Keputusan Presiden Nomor 53 Tahun 1989 tentang Pengembangan Kawasan Industri, Kabupaten Karawang ditetapkan sebagai daerah pengembangan kawasan industri, yang hingga saat ini jumlah industri mencapai 9.979 unit usaha. ${ }^{47}$ Menurut Nanang Kosim, Ketua Perkumpulan Penyandang Disabilitas Indonesia (PPDI) Karawang, Pemkab Karawang terkesan menganaktirikan penyandang keterbatasan fisik di daerahnya. Padahal, penyandang disabilitas ingin disejajarkan dengan masyarakat pada umumnya. Disebutkan, setiap tahun "kaum difabel" di Karawang memang mendapat pelatihan dari Dinas Sosial setempat. Hal tersebut belum optimal, sebab penyandang disabilitas juga membutuhkan lapangan kerja atau permodalan. ${ }^{48}$

Berbeda kasus yang terjadi di PT Mondelez Indonesia, Klari, Kabupaten Karawang, pengusaha melakukan Pemutusan Hubungan Kerja (PHK) terhadap 98 orang buruh. Satu orang dari 98 orang buruh yang dikenai PHK, di antaranya adalah Jumhadi, buruh yang mengalami cacat permanen. Jumhadi mengalami cacat permanen akibat kecelakaan kerja pada tahun 2008 di PT Mondelez
Indonesia. Jari-jari tangan kanannya habis tergilas mesin pencetak kue. Sebagai korbankecelakaan kerja di perusahaan yang memproduksi makanan ringan biskuat ini, menyatakan penolakannya terhadap PHK sepihak yang menurutnya sama sekali tidak manusiawi. Salah satu rekan Jumhadi yang juga dikenai PHK, Teddy Gantika, sangat menyayangkan keputusan itu. Menurutnya melakukan PHK terhadap buruh yang mengalami cacat permanen sangatlah tidak manusiawi karena korban akan sulit mendapatkan pekerjaan baru. Buruh menduga salah satu alasan yang melatarbelakangi PHK tersebut adalah perusahaan melakukan pensiun dini terhadap karyawan yang produktivitasnya dinilai rendah, yakni buruh yang berusia lanjut, cacat fisik, dan korban kecelakaan kerja. Tidak peduli jika buruh-buruh yang bersangkutan telah berkontribusi bagi kemajuan perusahaan di masa lalu. Hal tersebut menjadi dugaan yang mungkin benar, karena sebelum diadakannya pertemuan membahas PHK, pengusaha sempat menyarankan agar buruh mengambil pensiun dini. ${ }^{49}$

Peraturan atau regulasi yang lebih rendah terkait dengan pelatihan kerja dan penempatan tenaga kerja penyandang disabilitas, yaitu melalui Keputusan Menteri Tenaga Kerja dan Transmigrasi RI Nomor KEP-205/MEN/1999 tentang Pelatihan Kerja dan Penempatan Tenaga Kerja Penyandang Cacat, serta Surat Edaran Menteri Nomor 01.KP.01.15.2002 tentang Penempatan Tenaga Kerja Penyandang Cacat di Perusahaan. Pemerintah Kabupaten Karawang belum mempunyai peraturan perundang-undangan khusus mengenai tenaga kerja penyandang disabilitas. Kebutuhan terhadap pengaturan perlindungan hukum bagi penyandang disabilitas masih dianggap sebagai subjek yang

45 Komisi Pemilihan Umum, "Data Pemilih Tetap Pilkada Serentak Tahun 2015", https://data.kpu.go.id/dpt2015.php, diakses 21 November 2017.

46 Lalu Husni, 2012, Pengantar Hukum Ketenagakerjaan Indonesia, PT RajaGrafindo Persada, Jakarta. hlm. 26.

47 Desi, "Pembukaan Sosialisasi Kebijakan Penanaman Modal dalam Rangka Pengendalian Penanaman Modal Tahun 2016", http://www. karawangkab.go.id/berita/pembukaan-sosialisasi-kebijakan-penanaman -modal-dalam-rangka-pengendalian-penanaman-modal, diakses 9 April 2018.

48 Dodo Rihanto, "Para Penyandang Disabilitas di Karawang Minta Diperhatikan", https://www.pikiran-rakyat.com/jawa-barat/2017/10/15/ para-penyandang-disabilitas-di-karawang-minta-diperhatikan-41156 9, diakses 21 November 2017.

49 Erniyanti, "Pabrik Biskuat Pecat Buruh Korban Kecelakaan Kerja", http://www.solidaritas.net/pabrik-biskuat-pecat-buruh-korbankecelakaan-kerja/, diakses 11 Februari 2017. 
perlu dikasihani secara sosial, bukan memenuhi hak yang setara dengan warga lainnya, terutama masalah hak atas pekerjaan. Hal tersebut dapat dilihat berdasarkan Pasal 5 ayat (2) Peraturan Daerah Kabupaten Karawang Nomor 8 Tahun 2012 tentang Penyelenggaraan Kesejahteraan Sosial menyebutkan bahwa:

“(2). Penyandang Masalah Kesejahteraan Sosial (PMKS) sebagaimana dimaksud pada ayat (1), meliputi: (...) g. penyandang cacat/ penyandang disabilitas". 50

Berdasarkan penelitian yang dilakukan, Dinas Tenaga Kerja dan Transmigrasi Kabupaten Karawang mempunyai Balai Latihan Kerja (BLK) yang terus melakukan inovasi terhadap apa yang menjadi keperluan perusahaan guna mewujudkan masyarakat yang menginginkan untuk bekerja di pabrik. Balai Latihan Kerja merupakan wadah untuk menampung kegiatan pelatihan. Selain itu untuk memberikan, memperoleh, meningkatkan, serta mengembangkan keterampilan, produktivitas, disiplin, sikap kerja, dan etos kerja yang pelaksanaannya lebih mengutamakan praktek daripada teori. Kendati relevansi kedua hal itu sangat dibutuhkan secara seimbang dan perlu penekanan yang tepat di era globalisasi kini.

Selain melalui pelatihan di Balai Latihan Kerja, Dinas Tenaga Kerja, dan Transmigrasi, Kabupaten Karawang juga mempunyai program peningkatan kesempatan kerja bagi penyandang disabilitas, yaitu Program Peningkatan Kesempatan Kerja Kegiatan Pemberdayaan Tenaga Kerja Mandiri Penciptaan Wirausaha Baru Tenaga Kerja Disabilitas di Kabupaten Karawang. Pelatihan yang sudah dilakukan adalah seperti pelatihan sablon, pelatihan servis handphone, dan lainnya. ${ }^{51}$ Dasar hukum peraturan pelaksana kegiatan tersebut adalah Peraturan Pemerintah Nomor 33 Tahun 2013 tentang Perluasan Kesempatan Kerja.

Menurut Nanang Kosim, Ketua DPC Perkumpulan Penyandang Disabilitas Indonesia Kabupaten Karawang, menyebutkan bahwa kendala yang dihadapi oleh para penyandang disabilitas adalah kriteria pendidikan minimal SMA sederajat dalam persyaratan pelatihan maupun persyaratan lowongan pekerjaan pada perusahaan, kenyataannya rata-rata pendidikan yang dimiliki para penyandang disabilitas di Kabupaten Karawang adalah SD sederajat atau SMP sederajat. Seperti diketahui bahwa Sekolah Luar Biasa di Kabupaten Karawang hanya ada di perkotaan, jadi aksesibilitas terhambat jarak tempuh bagi penyandang disabilitas dari pedesaan. $^{52}$ Hak atas pendidikan penyandang disabilitas telah dijamin dalam Pasal 40 ayat (3) UU Penyandang Disabilitas yang menyebutkan bahwa:

"Pemerintah dan Pemerintah Daerah wajib mengikutsertakan anak penyandang disabilitas dalam program wajib belajar 12 (dua belas) tahun". ${ }^{3}$

Berdasarkan hasil penelitian diketahui bahwa Dinas Sosial Kabupaten Karawang ikut berperan dalam upaya peningkatan kesempatan kerja melalui Loka Bina Karya berupa pelatihan tata boga, menjahit, cukur rambut, dan lain-lain. Selain itu juga Dinas Sosial berperan dalam menginformasikan kepada penyandang disabilitas untuk mendapatkan pelayanan rehabilitasi dari Balai Besar Rehabilitasi Vokasional Bina Daksa (BBRVBD). ${ }^{54}$

50 Pasal 5 ayat (2) Peraturan Daerah Kabupaten Karawang Nomor 8 Tahun 2012 tentang Penyelenggaraan Kesejahteraan Sosial Lembaran Daerah Kabupaten Karawang Tahun 2012 Nomor: 8.

51 Hasil Wawancara dengan Irma Hermayati, Bidang Bina Penempatan dan Perluasan Tenaga Kerja Disnakertrans Kabupaten Karawang, pada tanggal 20 Maret 2018.

52 Hasil Wawancara dengan Nanang Kosim, Ketua DPC Perkumpulan Penyandang Disabilitas Indonesia Kabupaten Karawang, pada tanggal 23 Maret 2018.

53 Pasal 40 ayat (3) Undang-Undang Nomor 8 Tahun 2016 tentang Penyandang Disabilitas (Lembaran Negara Republik Indonesia Tahun 2016 Nomor 69, Tambahan Lembaran Negara Republik Indonesia Nomor 5817).

54 Ibid. Selain dari itu terdapat juga Balai Besar Rehabilitasi Vokasional Bina Daksa (BBRVBD) yang merupakan salah satu Unit Pelaksana Teknis Rehabilitasi Vokasional untuk penyandang disabilitas fisik di lingkungan Kementerian Sosial Republik Indonesia yang berada di bawah dan bertanggung jawab kepada Direktur Jenderal Rehabilitasi Sosial. Seiring dengan perkembangannya, BBRVBD mempunyai tujuan akhir menjadikan penyandang disabilitas fisik sebagai calon tenaga kerja yang terampil dan profesional siap bersaing di dunia kerja. 
2. Akibat Hukum Terhadap Perusahaan yang Tidak Mempekerjakan Paling Sedikit 1\% (satu persen) Penyandang Disabilitas dari Jumlah Pekerja di Kabupaten Karawang

Perusahaan yang mempekerjakan pekerja penyandang disabilitas wajib memenuhi hak pekerja penyandang disabilitas seperti pekerja lainnya. Menurut Pasal 50 ayat (4) UU Penyandang Disabilitas menyebutkan bahwa:

"Pemberi Kerja yang tidak menyediakan Akomodasi yang Layak dan fasilitas yang mudah diakses oleh tenaga kerja Penyandang Disabilitas dikenai sanksi administratif berupa: (a) Teguran tertulis; (b) Penghentian kegiatan operasional; (c) Pembekuan izin usaha; dan (d) Pencabutan izin usaha". ${ }^{55}$

Sebagai ilustrasi misalnya, Hotel Dharmawangsa adalah hotel mewah bintang lima yang berlokasi di Jakarta Selatan. Hotel ini dibuka pada tahun 1997 dan mempekerjakan 350 karyawan untuk total 100 kamar. Saat ini terdapat dua orang penyandang disabilitas yang bekerja di hotel tersebut. Salah satu dari mereka memiliki gangguan pendengaran dan bekerja sebagai asisten koki di dapur restoran hotel. Sebagai lulusan sekolah perhotelan dan dipekerjakan berdasarkan keahlian dan kemampuannya. Cara berkomunikasinya yaitu dengan membaca bibir dan komunikasi tertulis. Eril SA, Manajer SDM hotel, telah berlatih bahasa isyarat untuk membantu berkomunikasi dengannya. ${ }^{56}$

Penyandang disabilitas yang seorang lagi bekerja sebagai staf pencatat waktu keamanan di hotel tersebut. Kecelakaan motor menjadi penyebab kekurangan fisiknya dan pada awalnya berniat untuk mengundurkan diri dari pekerjaannya. Berpikir bahwa dengan menjadi disabilitas maka tidak dapat lagi bekerja untuk hotel tersebut. Faktanya adalah dikarenakan dia telah lama bekerja dan juga karena kemampuannya, pihak manajemen hotel tidak menemukan alasan untuk menerima pengunduran dirinya dan memintanya untuk tetap bekerja di jajaran keamanan hotel. ${ }^{57}$

Isu penting untuk memberikan kesempatan bagi pekerja yang mengalami cedera untuk tetap mempertahankan pekerjaan mereka meskipun kecelakaan yang mereka alami berdampak seumur hidup. Upaya untuk mempertahankan anggota staf apapun yang terjadi pada mereka selama atau setelah jam kerja, memperkuat relasi majikan-pekerja dan meningkatkan komitmen terhadap pekerjaan, karena mereka mengetahui bahwa perusahaan peduli pada mereka. ${ }^{58}$

Berdasarkan keterangan dari Dinas Tenaga Kerja dan Transmigrasi Kabupaten Karawang bahwa pihaknya tidak mengetahui pasti jumlah perusahaan di Kabupaten Karawang yang mempekerjakan penyandang disabilitas paling sedikit 1\% (satu persen) dari jumlah pekerja. ${ }^{59}$ Begitu juga dari pihak Dinas Tenaga Kerja dan Transmigrasi Provinsi Jawa Barat UPTD Pengawasan Ketenagakerjaan Wilayah II belum melakukan inventarisasi data perusahaan yang mempekerjakan penyandang disabilitas. Berdasarkan keterangan, Bapak Nursyamsi menyebutkan bahwa UPTD Pengawasan Ketenagakerjaan hanya mengawasi ketenagakerjaan yang dimuat dalam Undang-Undang Nomor 13 Tahun 2003 tentang Ketenagakerjaan dan peraturan pelaksananya. Ketentuan kuota pekerja penyandang disabilitas dimuat dalam UU Penyandang Disabilitas. ${ }^{60}$

Surat Edaran Menteri Nomor 01.KP.01. 15.2002 tentang Penempatan Tenaga Kerja Penyandang Cacat di Perusahaan yang ditujukan

\footnotetext{
55 Pasal 50 ayat (4) Undang-Undang Nomor 8 Tahun 2016 tentang Penyandang Disabilitas (Lembaran Negara Republik Indonesia Tahun 2016 Nomor 69, Tambahan Lembaran Negara Republik Indonesia Nomor 5817).

56 Nur Kholis, "Mempekerjakan Penyandang Disabilitas: Pedoman Untuk Perusahaan", https://www.scribd.com/document/359307485/20130201Employing-Persons-with-Disabilities-Guideline-Indonesia-Final-pdf, diakses 14 Maret 2018.

59 Hasil wawancara dengan Irma Hermayati, Bidang Bina Penempatan dan Perluasan Tenaga Kerja Disnakertrans Kabupaten Karawang, 20 Maret 2018

60 Hasil wawancara dengan Nursyamsi, Pengawas Ketenagakerjaan Disnakertrans Provinsi Jawa Barat UPTD Pengawasan Ketenagakerjaan Wilayah II, 20 Maret 2018.
} 
kepada Kepala Dinas yang bertanggung jawab di bidang ketenagakerjaan di Provinsi dan Kabupaten/ Kota, diperintahkan oleh Menteri Tenaga Kerja dan Transmigrasi untuk mensosialisasikan, mendata, dan melaporkan hasil pendataan perusahaan yang telah mempekerjakan tenaga kerja penyandang cacat kepada Menteri. Pemerintah Kabupaten Karawang dapat ikut serta dalam berbagai perbuatan hukum perdata, dengan ikut mempengaruhi hubungan hukum keperdataan yang berlangsung di masyarakat umum. ${ }^{61}$

Pengusaha berorientasi paradigma ekonomis produktif, merekrut tenaga kerja penyandang disabilitas dinilai tidak ekonomis dengan pertimbangan keterbatasan dan aksesibilitas (pendaftaran, seleksi, penerimaan, dan keberlanjutan kerja). Pemerintah Kabupaten Karawang sebagai pihak dalam hubungan industrial kurang melakukan sosialisasi melalui Kementerian Ketenagakerjaan Cq. Dinas Tenaga Kerja dan Transmigrasi tentang kuota $1 \%$ (satu persen). Pemerintah Cq. Kementerian Ketenagakerjaan seharusnya menerbitkan surat edaran yang ditujukan kepada instansi pemerintah lintas sektor dan perusahaan swasta yang menegaskan bahwa syarat "sehat jasmani dan rohani" tidak dimaksudkan untuk membatasi/ menghilangkan kesempatan penyandang disabilitas dalam mendapatkan pekerjaan, di mana hal tersebut selalu dicantumkan dalam informasi lowongan kerja.

Pemerintah Kabupaten Karawang dapat mencontoh peraturan daerah lain terkait tenaga kerja penyandang disabilitas, sebagaimanayang dilakukan Pemerintah Kota Mojokerto yang ikut andil dalam hukum keperdataan dalam hubungan kerja antara perusahaan dan tenaga kerja penyandang disabilitas, dengan membuat produk hukum berupa Peraturan Daerah Pemerintah Kota Mojokerto Nomor 15 Tahun 2015 tentang Pengaturan Ketenagakerjaan
Bagi Penyandang Disabilitas. Peraturan Daerah tersebut mengatur mulai dari perekrutan hingga pasca bekerja. Tata cara perekrutan dan penempatan kerja, bentuk hubungan kerja, dan perjanjian kerja hingga prosedur pemutusan hubungan kerja bagi penyandang disabilitas. ${ }^{62}$

Dalam hal tidak dipenuhinya hak akibat adanya perbedaan pelaksanaan atau penafsiran terhadap ketentuan peraturan perundang-undangan, perjanjian kerja, peraturan perusahaan, atau perjanjian kerja bersama, maka perselisihan ini merupakan perselisihan hak. Perselisihan hak ini mengandung arti bahwa "hak" itu sudah ada, baik yang lahir karena ketentuan hukum atau lahir karena perjanjian. ${ }^{63}$ Menurut hukum perdata apabila salah satu pihak melanggar aturan hukum (tidak melaksanakan kewajiban yang diatur oleh hukum), menyebabkan hilangnya hak orang lain. Sehubungan dengan hal di atas, maka perbuatan itu dapat dikualifikasikan sebagai perbuatan melanggar hukum. Apabila salah satu pihak tidak memenuhi kewajiban sebagaimana telah diatur dalam perjanjian, maka perbuatan itu dapat dikualifikasikan sebagai perbuatan "ingkar janji” atau wanprestasi. Untuk itu tenaga kerja penyandang disabilitas dapat melakukan gugatan dan meminta ganti rugi. ${ }^{64}$

Hal lain yang dapat dilakukan terkait ganti rugi, dapat berupa kewajiban pemberian bantuan dari perusahaan. Pemerintah Kabupaten Karawang dapat mencontoh Peraturan Daerah Kota Mojokerto dalam hal tindakan hukum terhadap perusahaan yang tidak mempekerjakan penyandang disabilitas paling sedikit 1\% (satu persen) dari jumlah pekerja di masa yang akan datang. Pasal 21 Peraturan Daerah Kota Mojokerto Nomor 15 Tahun 2015 tentang Pengaturan Ketenagakerjaan Bagi Penyandang Disabilitas menyebutkan bahwa: ${ }^{65}$

1. SKPD yang bertanggung jawab di bidang ketenagakerjaan memfasilitasi

\footnotetext{
61 Philipus M. Hadjon, Op.cit., hlm. 167.

62 Misti P, "Walikota Mojokerto Jadi Pembicara Seminar Nasional di Jakarta”, http://m.berita jatim.com/advetorial/312356/walikota_mojokerto jadi pembicara seminar nasional di jakarta.html, diakses 22 April 2018.

63 I Gusti Ngurah Adnyana, "Penjatuhan Sanksi dalam Penyelesaian Perselisihan Hubungan Industrial”, Jurnal Cakrawala Hukum, Vol. 19, No. 1,2014 , hlm. 31

64 Ibid., hlm. 32.
} 
pemenuhan kuota tenaga kerja disabilitas paling sedikit $1 \%$ (satu persen) pada perusahaan di Kota Mojokerto.

2. Perusahaan yang tidak memenuhi kuota sebagaimana dimaksud pada ayat (1) wajib untuk memberikan bantuan sebanyak 1 (satu) kali setiap tahun pada bulan Desember yang ditetapkan paling lambat setiap tanggal 28 Desember berupa:

a. uang;

b. peralatan bagi penyandang disabilitas; dan/atau

c. perlengkapan bagi penyandang disabilitas.

Kepada organisasi yang bergerak di bidang peningkatan kesejahteraan penyandang disabilitas di Kota Mojokerto yang telah terdaftar pada SKPD yang bertanggung jawab di bidang sosial.

3. Besaran bantuan sebagaimana yang dimaksud pada ayat (2) diberikan sesuai dengan kemampuan perusahaan dengan nilai paling sedikit jika dinilaikan dalam bentuk uang maka besarannya ditentukan sebesar Upah Minimum Kota Mojokerto yang berlaku saat itu dikalikan 14 (empat belas).

4. Organisasi penyandang disabilitas yang menerima bantuan sebagaimana yang dimaksud pada ayat (2) wajib membuat laporan pertanggungjawaban kepada SKPD yang bertanggung jawab di bidang sosial.

5. Tata cara pembuatan laporan pertanggungjawaban sebagaimana yang dimaksud pada ayat (4) diatur dengan Peraturan Walikota.

Berdasarkan konsep tersebut, penyandang disabilitas dapat meminta ganti rugi, dalam hal ini berupa bantuan dari perusahaan. Adanya peraturan perundang-undangan tersebut dapat menjadi tindakan hukum untuk memenuhi hak penyandang disabilitas karena tidak diberi kesempatan untuk dipekerjakan.

\section{Kesimpulan}

Berdasarkan hasil penelitian dan pembahasan yang telah diuraikan sebelumnya, maka dapat ditarik kesimpulan sebagai berikut: Pertama, aksesibilitas perlindungan hukum terhadap tenaga kerja bagi penyandang disabilitas di Kabupaten Karawang, baik bagi pencari kerja maupun para pekerja, dalam tataran kebijakan dan regulasi belum memiliki sinkronisasi dengan berbagai peraturan perundang-undangan yang berlaku, mulai dari Undang-Undang Dasar Negara Republik Indonesia Tahun 1945, Undang-Undang Nomor 8 Tahun 2016 tentang Penyandang Disabilitas, dan Peraturan Pemerintah Nomor 43 Tahun 1998 tentang Upaya Peningkatan Kesejahteraan Sosial Penyandang Cacat. Sedangkan Peraturan Daerah Kabupaten Karawang Nomor 8 Tahun 2012 tentang Penyelenggaraan Kesejahteraan Sosial, Pasal 5 ayat (2) hanya mengatur tentang penyandang disabilitas sebagai Penyandang Masalah Kesejahteraan Sosial (PMKS). Hal tersebut dapat ditandai dengan tidak adanya Peraturan Daerah yang khusus mengenai tenaga kerja Penyandang Disabilitas. Perlindungan hukum terhadap tenaga kerja penyandang disabilitas di Kabupaten Karawang seharusnya dimulai dari hak memperoleh kesempatan kerja tanpa diskriminasi, proses rekrutmen, penempatan tenaga kerja, dan perlindungan kerja. Perlindungan hukum terhadap tenaga kerja penyandang disabilitas belum dapat diimplementasikan sebagai pemenuhan hak yang merupakan kewajiban pemerintah daerah, khususnya berkaitan dengan hak memperoleh kesempatan kerja di perusahaan berdasarkan Pasal 53 ayat (2) Undang-undang Nomor 8 Tahun 2016 tentang Penyandang Disabilitas.

Kedua, akibat hukum terhadap perusahaan yang tidak mempekerjakan paling sedikit $1 \%$ (satu persen) penyandang disabilitas dari jumlah pekerja di Kabupaten Karawang, yaitu dengan melakukan tindakan hukum dalam hukum publik dan tindakan hukum dalam hukum privat. Tindakan hukum dalam

\footnotetext{
65 Pasal 21 Peraturan Daerah Kota Mojokerto Nomor 15 Tahun 2015 tentang Pengaturan Ketenagakerjaan Bagi Penyandang Disabilitas (Lembaran Daerah Kabupaten Karawang Tahun 2015 Nomor: 360-15/2015).
} 
hukum publik dapat dilakukan dengan memberikan sanksi pidana dan sanksi administratif, sedangkan tindakan hukum dalam hukum privat dengan meminta ganti rugi terhadap perusahaan yang dapat diatur secara konsisten dalam Peraturan Daerah Kabupaten Karawang tentang Penyelenggaraan Ketenagakerjaan mendatang. Perlu peraturan perundang-undangan yang baru, berupa Peraturan Pemerintah sampai dengan Peraturan Daerah di Kabupaten Karawang mengenai peraturan pelaksana tentang ketentuan tindakan hukum terhadap perusahaan yang tidak menjalankan kuota $1 \%$ (satu persen) pekerja penyandang disabilitas, sebagai contoh Peraturan Daerah Kota Mojokerto Nomor 15 Tahun 2015 tentang Pengaturan Ketenagakerjaan Bagi Penyandang Disabilitas. Perlu pengawasan yang ketat dari Dinas Tenaga Kerja dan Transmigrasi Provinsi Jawa Barat UPTD Pengawasan Ketenagakerjaan Wilayah II terhadap adanya kecelakaan kerja, sehingga tidak ada Pemutusan Hubungan Kerja terhadap pekerja yang mengalami cacat tetap (disabilitas) akibat kecelakaan kerja. Selain itu, perlu adanya Peraturan Daerah yang mengakomodir para pekerja yang mengalami Pemutusan Hubungan Kerja. Perlu optimalisasi peranan Pemerintah Daerah Kabupaten Karawang dalam memenuhi hak bagi Penyandang Disabilitas. Salah satunya dengan melindungi tenaga kerja Penyandang Disabilitas di Kabupaten Karawang dapat efektif dijalankan dan dipatuhi perusahaan/instansi, maka diperlukan pengaturan yang aplikatif dengan memberikan penerapan sanksi yang memberikan efek jera dan derita, serta diperlukan pengawasan oleh pegawai pengawas pada Dinas Tenaga Kerja dan Transmigrasi Provinsi atau Kabupaten/Kota terhadap perusahaan serta peran serta masyarakat.

\section{DAFTAR PUSTAKA}

\section{A. Buku}

Asyhadie, Zaeni, 2015, Hukum Kerja: Hukum Ketenagakerjaan Bidang Hubungan Kerja, PT RajaGrafindo Persada, Jakarta.

Djamali, R. Abdoel, 2014, Pengantar Hukum Indonesia, PT RajaGrafindo Persada, Jakarta.

Hadjon, Philipus M., et al., 2016, Argumentasi Hukum, Gadjah Mada University Press, Yogyakarta.

Heymann, Jody, et al., 2013, Disability and Equity at Work, Oxford University Press, UK.

Husni, Lalu, 2012, Pengantar Hukum Ketenagakerjaan Indonesia, PT RajaGrafindo Persada, Jakarta.

Jurdi, Fajlurrahman, 2017, Logika Hukum, Penerbit Kencana, Jakarta.

Khakim, Abdul, 2014, Dasar-Dasar Hukum Ketenagakerjaan Indonesia, Cetakan ke-4, PT Citra Aditya Bakti, Bandung.

Muhtaj, Majda El, 2008, Dimensi-dimensi HAM Mengurai Hak Ekonomi, Sosial dan Budaya, PT RajaGrafindo Persada, Jakarta.
Riyanto, Sigit, et. al., 2013, Keterampilan Hukum: Panduan untuk Mahasiswa, Akademisi dan Praktisi, Gadjah Mada University Press, Yogyakarta.

Schmid, JJ. von, 1962, Ahli-ahli Pemikir Besar tentang Negara dan Hukum (dari Plato sampai Kant), (Diterjemahkan oleh R. Wiranto, et al.), PT Pembangunan, Jakarta.

Simanjuntak, Payaman J., 1985, Pengantar Ekonomi Sumber Daya Manusia, Fakultas Ekonomi UI, Jakarta.

Soekanto, Soerjono, et al., 2011, Penelitian Hukum Normatif, Suatu Tinjauan Singkat, PT RajaGrafindo Persada, Jakarta.

Soepomo, Iman, 1985, Pengantar Hukum Perburuhan, Djambatan, Jakarta.

\section{B. Artikel Jurnal}

Adnyana, I Gusti Ngurah, "Penjatuhan Sanksi dalam Penyelesaian Perselisihan Hubungan Industrial", Jurnal Cakrawala Hukum, Vol. 19, No. 1, 2014. 
Irawan, Andrie, "Peranan Pemerintah Daerah Istimewa Yogyakarta Dalam Perlindungan Hukum Terhadap Perempuan Penyandang Disabilitas Korban Kekerasan”, Jurnal Ilmiah Hukum De'Jure: Kajian Ilmiah Hukum, Vol. 2, No. 2, 2017.

Jackson, Mary Ann, "Models of Disability and Human Rights: Informing the Improvement of Built Environment Accessibility for People with Disability at Neighborhood Scale?" Laws, Vol. 7, 10, 2018.

Lestari, Eta Yuni, et al., "Pemenuhan Hak Bagi Penyandang Disabilitas di Kabupaten Semarang Melalui Implementasi Convention on The Rights of Persons with Disabillities (CPRD) Dalam Bidang Pendidikan", Integralistik, No.1/Th. XXVIII/2017, Januari-Juni 2017.

Shaleh, Ismail, "Implementasi Pemenuhan Hak Bagi Penyandang Disabilitas Ketenagakerjaan di Semarang”, Kanun: Jurnal Ilmu Hukum, Vol. 20, No. 1, April 2018.

\section{Internet}

Badan Pusat Statistik Kabupaten Karawang, "Kabupaten Karawang dalam Angka 2017", https:// karawangkab.bps.go.id/publication/2017/08 /17/258839c82b4aaf001be0f08f/kabupatenkarawang-dalam-angka-2017.html, diakses 20 November 2017.

Desi, "Pembukaan Sosialisasi Kebijakan Penanaman Modal dalam Rangka Pengendalian Penanaman Modal Tahun 2016", http:// www.karawangkab.go.id/berita/pembukaansosialisasi-kebijakan-penanaman-modaldalam-rangka-pengendalian-penanamanmodal, diakses 9 April 2018.

Erniyanti, "Pabrik Biskuat Pecat Buruh Korban Kecelakaan Kerja", http://www.solidaritas. net/pabrik-biskuat-pecat-buruh-korbankecelakaan-kerja/, diakses 11 Februari 2017.

Kholis, Nur, "Mempekerjakan Penyandang Disabilitas: Pedoman Untuk Perusahaan", https:// www.scribd.com/document/359307485/
20130201-Employing-Persons-with-Disabilities-Guideline-Indonesia-Final-pdf, diakses 14 Maret 2018.

Komisi Pemilihan Umum, "Data Pemilih Tetap Pilkada Serentak Tahun 2015", https://data. kpu.go.id/dpt2015.php, diakses 21 November 2017.

P, Misti, "Walikota Mojokerto Jadi Pembicara Seminar Nasional di Jakarta", http://m. beritajatim.com/advetorial/312356/ walikota_mojokerto_jadi_pembicara_ seminar_nasional_di_jakarta.html, diakses 22 April 2018.

Rihanto, Dodo, "Para Penyandang Disabilitas di Karawang Minta Diperhatikan", https://www. pikiran-rakyat.com/jawa-barat/2017/10/15/ para-penyandang-disabilitas-di-karawangminta-diperhatikan-41156 9, diakses 21 November 2017.

\section{Peraturan Perundang-undangan}

Undang-Undang Dasar Negara Republik Indonesia Tahun 1945.

Undang-Undang Nomor 39 Tahun 1999 tentang Hak Asasi Manusia (Lembaran Negara Republik Indonesia Tahun 1999 Nomor 165, Tambahan Lembaran Negara Republik Indonesia Nomor 3886).

Undang-Undang Nomor 13 Tahun 2003 tentang Ketenagakerjaan (Lembaran Negara Republik Indonesia Tahun 2003 Nomor 39, Tambahan Lembaran Negara Republik Indonesia Nomor 4279).

Undang-Undang Nomor 40 Tahun 2004 tentang Sistem Jaminan Sosial Nasional (Lembaran Negara Republik Indonesia Tahun 2004 Nomor 150, Tambahan Lembaran Negara Republik Indonesia Nomor 5256).

Undang-Undang Nomor 8 Tahun 2016 tentang Penyandang Disabilitas (Lembaran Negara Republik Indonesia Tahun 2016 Nomor 69, Tambahan Lembaran Negara Republik Indonesia Nomor 5817).

Peraturan Daerah Kabupaten Karawang Nomor 
8 Tahun 2012 Tentang Penyelenggaraan Kesejahteraan Sosial (Lembaran Daerah Kabupaten Karawang Tahun 2012 Nomor: 8).

Peraturan Daerah Kota Mojokerto Nomor 15 Tahun 2015 tentang Pengaturan Ketenagakerjaan Bagi Penyandang Disabilitas (Lembaran Daerah Kabupaten Karawang Tahun 2015 Nomor: 360-15/

\section{E. Hasil Wawancara}

Hasil Wawancara dengan Irma Hermayati, Bidang
Bina Penempatan dan Perluasan Tenaga Kerja Disnakertrans Kabupaten Karawang, pada tanggal 20 Maret 2018.

Hasil Wawancara dengan Nanang Kosim, Ketua DPC Perkumpulan Penyandang Disabilitas Indonesia Kabupaten Karawang, pada tanggal 23 Maret 2018.

Hasil Wawancara dengan Nursyamsi, Pengawas Ketenagakerjaan Disnakertrans Provinsi Jawa Barat UPTD Pengawasan Ketenagakerjaan Wilayah II, 20 Maret 2018. 